\title{
Sati - suicide by widows sanctioned by Hindu scriptures and society?
}

\author{
By Latha Nrugham
}

\section{Introduction}

In India, sati is the term usually applied to a Hindu widow dressed as a bride ceremoniously ascending alive the funeral pyre of her dead husband and being burnt to ashes on that pyre. Such a person is said to have become a sati by this deed, one who did not become a widow, but remained a wife until her last breath.

Outside India, the word sati is commonly understood as suicide sanctioned by Hindu scriptures and widely practiced in India today. In order to comment on this understanding, I will first describe sati in the Hindu scriptures and then present sati in practice today. Marriage is a sacred inviolable bond, according to Vedic (Hindu in popular imagination and usage) scriptures.

\section{ABSTRACT}

The word sati is commonly understood as suicide by self-immolating widows widely practiced in India today and sanctioned by ancient Hindu scriptures, although it is also claimed that Hindu scriptures condemn suicide. Without delving into details, the scriptural understanding of satiand the history of sati alongwith its practice today will be described and discussed. Is sati suicide or is it something else, for example, murder?

Ordet sati blir gjerne forstått som et utbredt hindurituale av enker som tenner på seg selv til døden sammen med sine ektemenn, som foreskrevet i gamle hinduskrifter, selv om det også hevdes at hinduskriftene fordømmer selvmord. Forståelsen av sati og satis historie, samt dagens praksis i India, blir i denne artikkelen beskrevet og diskutert. Er sati selvmord eller noe annet - for eksempel mord?

LEVERT: 01/12-12 REVIDERT: 09/04-13 AKSEPTERT: 19/04-13
It is not a contract between two individuals but is the union of two individuals coming together in all ways to support each other for the goals of life laid down in the Vedic scriptures.

I refer to the Vedic scriptures because they are several texts, not one book. These texts can be grouped into two: Shruti (heard) and Smriti (remembered). Shruti has verses that are composed as a result of stable consciousness states of insight resulting from deep meditation for several years and has three divisions: the four Vedas, the main Upanishads and the Brahmasutras. On the other hand, Smriti is composed by human intelligence in the ordinary waking consciousness and contains a mix of historical and metaphorical stories. Whenever there is a conflict between the Shruti and the Smriti, Shruti has precedence in all ways. Smriti changes over time and adjusts to changing social conditions. Shruti endures all social changes. I present my understanding after a long study of texts from both, Shruti and Smriti. I have not examined all the Vedic texts, yet claim that I possess an understanding of the main texts which is adequate to comment on sati in them.

\section{Meaning of the word sati}

The word 'sati' has many meanings, as is usual in Sanskrit. The most easily understood meaning is: she who is the embodiment of truth (sat = truth, $i=$ indicative of feminity). Another meaning is she who is the personification of spiritual knowledge itself, the consort of the personification of Absolute Auspiciousness (shiva). Yet another meaning is that of a faithful wife, as her resolve and words are equal to truth itself. It is this third meaning that is one of the two commonly used meanings today. Another meaning of sati understood today is of a wife who decides to ascend while still alive, the funeral pyre of her dead husband making his funeral pyre equally hers. Such a person was and is considered equal to divinity, having transcended, while alive, human qualities such as distress about and fear of damage to body issue and death itself, in addition to being endowed with the ability to endure fire in silence. A wife, who was also a mother or pregnant, could not consider sati, as that would make the child an orphan.

\section{Sati in the Vedic scriptures}

Vedic scriptures do not have a central authority like the Pope for Christians or even organised dissemination of its contents like Islamic madrassas (schools of Quran) or the Sunday schools of Christianity. They wait for the ordinary individual to approach them and work their own ways through the maze of syntax and semantics before taking notice. However, the vast majority of persons in society could not be left without spiritual knowledge. And the potential for the others becoming deviated from/weakened in their resolve to pursue individual spiritual goals being high, the scriptures had to be so pervasive in society that all human beings encountered the same contents, in some form or the other, during daily life. Therefore, the spiritual knowledge (shruti) which a brahmin (teachers of spiritual knowledge, preferably after selfverification, but maybe applied to all those whose wealth is knowledge, any knowledge) was expected to learn, grasp, realise and share to a greater extent with competent others was made simple and spread throughhout society in the form of stories (smriti) that could capture the imagination of and be understood by even children.

Abstract concepts are personified and named in a slightly disguised or undisguised manner in these stories so that relationships could be easily understood by the simplest of minds with minimal effort, for example: Dharma (righteousness) marries Daya (compassion) to beget Abhaya (fearlessness), Dharma marries Unnati (growth through accomplishment) to beget Darpa (superciliousness/ contempt for others), Dharma marries Pushti (abundance) to beget Garva (pride/arrogance), 
Krodha (anger) marries Himsa (violence), Suruchi (one who is pleasant/tends towards the pleasures) has Kumati (unhealthy intellectual qualities) as her servant and Sumati (one who is ruled by the intellect, not the emotions and therefore tends away from pleasures) as her elder co-wife, Jatila (rigidity) is the sister of Abhimanyu (one who is quick to defend his personal pride). It is in these smriti stories that one first comes across the word 'sati', among Kshatriyas, the rulers, warriors and administrators.

Manusmriti, one of the texts which has no stories but provides codes of conduct and was considered important from the 1800 s to the 1900s, does not mention 'sati' as a practice for young widows.

There are verses in some Smriti texts which support or encourage sati as one of the courses open to a widow. However, these texts are not considered to be of high status even within the Smriti itself and therefore have no status at all as guide for living life or dying. One of these Smriti texts forbid sati for Brahmin widows. The Mahabharata, one of the two epics and part of Smriti, mentions a widow, Madri, who chose to accompany her husband on the funeral pyre. Madri was the younger wife and considered herself responsible for her husband's death. Overcome by guilt, not just the distress of bereavement, she is the only person in the scriptures who chose this way to die, despite being mother of two young sons. Her decision or death is neither referred to as sati nor glorified in any manner in the Mahabharata. Neither is it condemned. Although attempts to make Madri reconsider her decision were made, she was not forced to live. Madri's co-wife, Prtha, lived on as a widowed mother and singlehandedly brought up all five sons of her husband. Prtha's decision or life is neither glorified nor condemned. The ceremonies and festivals which Hindus follow, have their roots in Smriti stories, hence the attitudes in the Smriti on events are important.

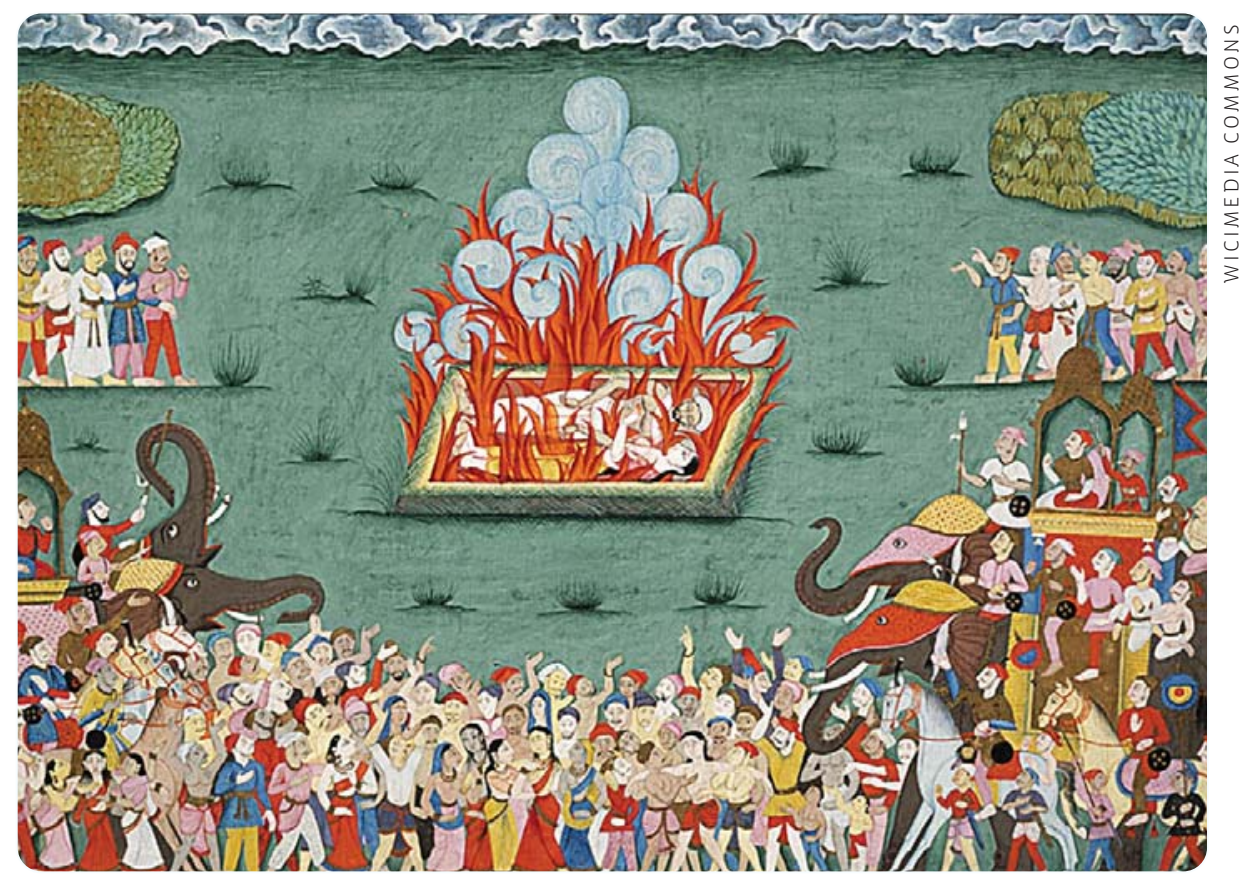

The Sati of Ramabai, wife of Madhavrao Peshwa (reigned 1761-1772), circa 1772-1775

\section{Sati - in practice}

An incident in 1987 in Rajasthan where a young wife ascended the funeral pyre of her husband in the presence of a crowd watching this event sent shock waves throughout India which sat up for yet another round of introspection. Her death was followed by a court trial of the inlaws and family members of the widow, for murder, which ended in acquittal in 2004. The Prevention of Sati Act was also passed in 1987 which made it illegal to abet, glorify or attempt to commit sati. Abetment of sati, including coercing or forcing someone to commit sati is punishable by death sentence or life imprisonment, while glorifying sati is punishable with 1 to 7 years in prison. Due to the consistent efforts of a well-known social reformer, Raja Ram Mohan Roy and pressure from his group, the Brahmo Samaj, the British government banned sati in 1829 (Sarkar \& Sarkar, 2008). Before them, the Mughal rulers from Persia, under pressure due to the social reforms carried out by the Sikh Gurus, had also passed laws and decrees, banning sati. These very processes of social reform leading to the legal banning sati by the Mughals and the British indi- cate that the burning of widows were not isolated incidents then. It is important to note that Brahmo Samaj was from Bengal, in the north-east of India. The property laws of Bengal provide an equal part for widows as it did to other inheritors. The widows of Bengal have suffered much on account of these laws by being socially ostracised, burnt or simply cast out to fend for themselves in any way they can, purely in order to deprive them of their rightful inheritance. Bengal has documented 706 cases of sati in a single year: 1817; the same year when Bengal was hit hard by a cholera pandemic (Sarkar \& Sarkar, 2008).

What could motivate a woman to ascend alive a funeral pyre, during peace times, apart from political goals? Is it suicide, sanctioned by scriptures? As she does not live to enjoy worldly gains, could such a death be an escape route from the ascetic life that she is expected to lead as a widow or is it an emotional decision due to the distress of the bereavement? Without children, young and perhaps beautiful, would such a death be preferable to possible sexual assaults from any male stronger than the ones who could protect her, or even worse, from her very protectors? 
Or is this a clamp-down on her sexuality and fertility from being expressed in any manner, from being used by other males, who might even want to marry her? Is it disguised murder, sanctioned by scriptures? Or is it seen as a short-cut to moksha, skipping the stages of spiritual development? Could she have been inspired by jauhar to make a go for glory in ballads and be remembered by sati stones worshipped by chaste wives and husbands desiring chaste wives? Old sati stones, with handprints, raised in memory of women who ascended the funeral pyres of their dead husbands are found in several places in North India.

Mass media reports indicate that 'sati' continues in India today, with one incident in 1999 (aged 55 years), one in 2002 (aged 65 years), two in 2006 (aged 35 and 45 years) and one in 2008 (aged 71 years). The word sati is used to refer to these dead women, although none of them had indicated in any manner that they intended to become sati and neither have their deaths been ceremonious. Commissions set up by the government to enquire into these events over and above the investigation by the local police and the mass media did not lead to any court trials, indicating that all three kinds of detailed and independent examinations could not bring any punishable offence or condemnable event to light (Kishwar, 2008). The prevalence is therefore not worth estimating, but it is disturbing that these events are considered as sati today. The use of the word sati in such a context points to the need for someone alive to benefit from the death of these women in some manner.

The Vedic scriptures do not sanction suicide, except as an optional penance for an offence by a brahmin, as a brahmin cannot be punished by anyone else. Individual spiritual goals are to be pursued by the individual who chose those goals and no other individual could act as proxy, not even a wife or a guru. Logically, spiritual goals cannot sanction murder,

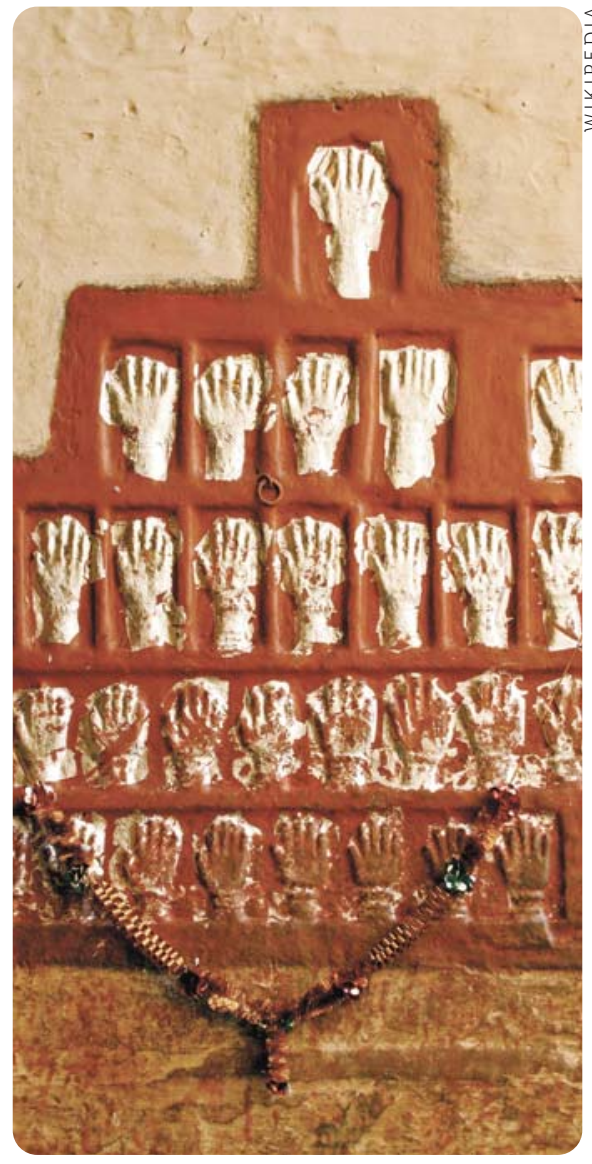

Handprints of Satis from the royal family of Jodhpur

under any form, no matter how welldisguised, as one of the first steps towards spiritual life in the Vedic scriptures is ahimsa (Johnston, 1912). Ahimsa is the practice of non-violence at the thought level, not just verbal or physical levels. No physical austerity, not even burning oneself, can lead to moksha, as moksha being an inner goal is completely dependent on the inner journey, the dissolution of the inner self, not the burning of the outer physical body. The instances mentioned in the stories of the Smritis are abstract concepts presented as personifications. The incidents observed in the last decades have more to do with social circumstances of the mourning widows than spiritual sanction or goal, according to investigations by social activists and journalists (Kishwar, 2008). When attempted suicide is mentioned in the Smriti, for example, of the highly respected sage Vashishta, it is not accompanied by glorification or condemnation but is presented as a description of the individual's intolerable inner agony. Murder, on the other hand, is condemned repeatedly and clearly, even if it is attempt to murder. There is a verse in the Isha Upanishad which is often quoted as condemning suicide. However, the Shruti, to which the Isha Upanishad belongs, has as its subject matter, the journey of the inner self to the Self, and not the physical body. The interpretation of the word aatma, which translates as 'self' is a word which has given rise to the several schools of theosophical thought, as it is seen to be used for the body, the personality, the individual, the mind, the individual soul and the universal soul.

Self-immolation, a physical act, regardless of whether it results in death, is a dramatic and horrifying event to the one who does it and also to those who witness it or come to know about it. The historians of Alexander from Macedonia report that a holy man, Kalanus, who had chosen to be with Alexander from India had immolated himself amongst the Greeks and Macedonians when he realised that he had become a slave to tasty food (McCrindle, 1896). This punishment that he accorded to himself, Alexander's historians state, was done as ceremoniously and in full public view as a sati has been described by foreign travellers from the west of the Sindhu river to India, such as Alberuni who accompanied the invader Mahmud of Ghazni (Sachau, 1910), and Marco Polo who is said to have inspired Christopher Columbus. However, I have not come across any mention of sati being a selfpunishment. These detailed accounts refer to beautiful, fearless and proud women being borne ceremoniously or to beautiful women whose screams for help are drowned by loud drums and their attempts to escape the fire are hindered actively by someone in the audience. Some travellers have been so touched by these events that they have painted what they saw (Hardgrave, 1998). 
On the other hand, the accounts of Chinese travellers to ancient India do not mention sati at all, although they also described the ordinary and the extraordinary in India in fairly comparable detail. I am not sure how this absence of a reference to sati from the accounts of Chinese travellers such as Huein Tsang, who came to India to study Buddhism can be explained. Selfimmolation is even today used as a manner of political protest, with Buddhists from Veitnam and Tibet being the most recent examples. Did the Chinese travellers consider the instances of widows dressed up as brides and ascending the funeral pyres of their husbands as a political protest of the condition of widows and therefore chose to remain silent? Or was it that they did not consider it worth mentioning because widows in ancient China had a somewhat similar fate? I do not know.

\section{Jauhar}

Another situation in which a wife would ascend alive a funeral pyre is known as 'jauhar' (Arabic for Hindi jivhar = to loose one's life). This practice is not allowed for a mother either and has the avoidance of rape of women by invaders as its sole objective. This practice came into being and stayed in use when Islamic invaders into Rajasthan, a north-western state of India, came in such strengths that it was extremely clear that the men who went to battle them would not return alive. The departure of men on this suicide mission was known as shaka and their only objective was to inflict maximum damage on the invading army by killing as many as possible. Before they left for certain death on the battlefield, their wives informed them of their decision to ascend the pyre, so that the warriors knew that: (a) their wives would not be raped by the victors in order to bear the children of the invaders as an insult to their community and (b) this was the final battle as there was no wife to return to. The women who ascended the pyre thus were led by the queen. They would also be dressed as brides, in full jewellery, so that the victors came into an 'empty house'.

Number of Dowry Deaths in India from 1989 to 2011

$\mathrm{N}$

14000

13000

12000

11000

10000

9000

8000

7000

6000

5000

4000

3000

2000

1000

0

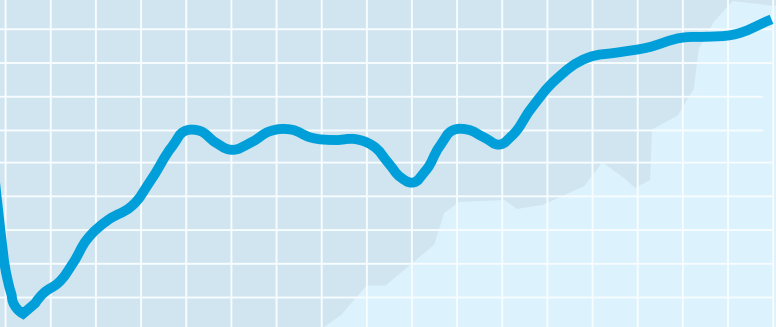

1990

1995

2000

2010

Data source: National Crime Records Bureau, India (http://ncrb.nic.in/)

This ascension was the last act performed within the closed fort as the rest of the populace would have fled to safer places. Such ascensions, therefore, had no witnesses. However, the oral and documented accounts of the invading victors turned these women into legends sung by bards and recited in ballads. The last known incident of jauhar was during the reign of Akbar, the Mughal who was the grandfather of the builder of the Taj Mahal. The practice of jauhar does not have a spiritual goal. It is a collective suicide pact only for kshatriyas at the lost end of a war, and also an individual choice. A jauhar cannot take place without the shaka and neither does the shaka take place without a jauhar, both decisions indicating the absence of any hope of successful defence of the fort or themselves. Jauhar, clearly suicide, is distinguished from sati due to the context of war and the women's group in which the ascension to the funeral pyre takes place.

\section{Dowry deaths - modern day version of sati?}

Self-immolation, in the India of the 1980s, was seen to alarming extents among young brides, mainly Hindus in North India. I remember that I read about atleast one such death every day in the newspapers during the early 1980s. These burnt brides would not give even a dying declaration against their husbands and in-laws, neither to the medical professionals and the police nor the judiciary who were called to their hospital bedsides. It was only when women activists were called to their bed-sides that the tales of unimaginable horror began to emerge.

What was until then accepted as suicides or accidents by young brides unable to adjust to the pressures of newly married life, now began to be called dowry deaths, 
as brides began to give dying declarations to women activists who would be present whenever the dying bride was admitted to the hospital by those very in-laws and husband who had done their best to burn her to death because she had failed to pressurize her father to give more gifts to her. Dowry, essentially the financial security that her family of origin can give to their daughter, had become a demand for gifts to the husband and in-laws, failing which she could be murdered.

The sheer numbers and the horror of each dying bride brought to light by women activists and journalists made the government of India speedily pass a law against such events and processes, by adding a sub-section to the Indian Penal Code itself. This rare event of changing the Code in 1984 stands today as section 498 (A), under which a mere complaint to the police by a wife within 3 years of her wedding can not only bring her husband and in-laws under the ambit of severe and swift criminal proceedings, but also make them loose their jobs, if employed by the government in any form. In 1986, the Code was changed again, whereby a nonnatural death of the wife within seven years of marriage made it a crime attributable to her husband and her relatives under section 304 (B).

The intent of the government was demonstrated in a few cases so well that dowry deaths declined sharply but are again rising now (http:// pib.nic.in/newsite (PrintRelease.aspx?relid=78178) - one death almost every hour. Anyone who brings even a hint of any process which can come under section 498(A) or 304 (B), usually receives attention from the police. This is not merely because the policemen/ women sympathise with the young wives in distress but also because if that police person's superiors come to know about any such delay or denial, that police person can risk loosing his/her job. As a young Indian woman, I was witness to these changes in urban and semi-urban India, from the vast numbers of brides dying by 'suicide' or accidents in the kitchen to the presence of sections $498(\mathrm{~A})$ and
304 (B) of the Indian Penal Code (see Graph 1). Most, if not all, of these dead or burnt brides, were married into Hindu families. Their deaths and lives, demonstrate, exactly how these families had nothing to do with the Vedic scriptures or what is popularly known as Hinduism, but were so consumed by greed that they did not hesitate to kill a young bride in order to bring in another bride. I waited in vain for girls and their families to take stands that they would not marry into families demanding dowries. Social pressure to get married and stay married was so high that the young women of North India risked death by burning, and their families of origin risked sending their daughters off to one of the most painful deaths possible, yet did not go against the dominance of families with males eligible for marriage. Those who were affected most, did not protest, even by a whisper or a glance. They submitted meekly to murder masquerading as suicide or accidents for more than five unfathomable years as these deaths spread across the cities and towns of most of North India and included the even then cosmopolitan Mumbai. The burning of women whose presence is found inconvenient despite an unfettered claim on her fertility leaves no doubt as to the possibility of the killing of women by burning, whether disguised as sati, or accident or suicide of widows whose fertility no longer has a male family member as a claimant. Dowry deaths have been considered to be modern day sati by leading Indian sociologists (Srinivas, 1984).

\section{Conclusion}

The Vedic scriptures describe a person known as Sati (Truth) who used her inner powers to create a fatal fire. She killed herself by fire in extreme anger and severe distress, not because of the death of her husband, Shiva (Auspiciousness, Absolute Truth), but because of the humiliation of her husband by her father Daksha (skill in action), the scriptures state. Her selfdestruction was a unmistakable protest against her father, whose daughter she no longer wished to be. She did not acquire the name Sati after her immolation, she was given that name on birth by her parents.

The probability of a wife ascending alive the funeral pyre of her dead husband for the spiritual goal of moksha and attaining it is null, with no known precedents. Every other instance of sati is murder, by commission or omission, motivated by greed. When brides are burnt so openly for greed, widows can be burnt more easily, without even a suspicion of murder clouding the presentation of a suicide or accident.

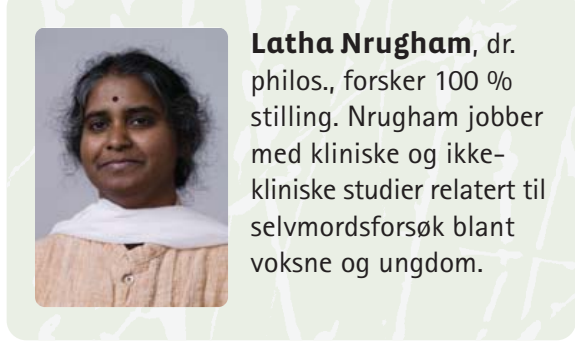

\section{References}

Hardgrave R.Jr. 1998. The Representation of Sati: Four Eighteenth Century Etchings by Baltazard Solvyns. In: Bengal: Past and Present. Vol 117. Calcutta Historical Society, 1998. http://www.laits. utexas.edu/solvyns-project/Satiart.rft.html

Johnston C, 1912. Yoga Sutras of Patanjali. http://www.sacred-texts.com/hin/ysp/ysp00.htm.

McCrindle, J.W. 1896. The Invasion of India by Alexander The Great. A Constable \&t Co, West-minister. http://archive.org/details/invasionofindiab 00mccr

Kishwar, M. 2008. Deadly Laws and Zealous Reformers: The Conflicting Interpretations and Politics Of Sati. In: Zealous Reformers, Deadly Laws: Battling Stereotypes. New Delhi, India ; Thousand Oaks, Calif.: Sage, 2008.

Sachau, E. 1910. Alberuni's India. http://www. columbia.edu/cu/lweb/digital/collections/cul/texts /ldpd_5949073_001/pages/ldpd_5949073_001_0 0000007.html

Sarkar S \& Sarkar T. (Eds.) Women and Social Reform in Modern India. A Reader. Indiana University Press. 2008.

Srinivas, M.N. Some Reflections on Dowry. Oxford University Press, Delhi. 1984. 